\title{
A MALAYSIAN PERSPECTIVE ON QUR'ĀNIC GOVERNANCE: FAMILY AUTONOMY vs. STATE INTERVENTION
}

\author{
Zaleha Kamaruddin*
}

\begin{abstract}
Good governance' is considered a crucial element for peace and development of societies, because it implies good order and good policies. In the context of the family institution, this is a must in order to ensure that the basic unit of society is protected from destruction. In relation to this, most scholars have acknowledged that all over the world, the family has undergone radical transformations in response to the changing socio-economic environment. However, the breadth and depth of this change in the realm of good governance has often been neglected. This article begins by examining contemporary challenges confronting the family institution. Justifications for state intervention through the existing family laws in Malaysia as one of the mechanisms in protecting the family will also be analysed. To ensure that family stability can be maintained and developed, 'qur'ānic governance' is proposed as a mechanism for social transformation.
\end{abstract}

\section{Introduction}

The main argument in this preliminary study is that the notion of 'good governance' should not be excluded from the area of family, since the family institution is very important for the growth and continuity of human civilisation at large. To ensure that family stability can be maintained and developed, a framework based on 'qur'ānic governance' is proposed as a mechanism for social transformation.

This article is divided into three parts. The first part discusses current challenges facing the family institution which includes various changes in the family structure, norms, values and behaviour. It suggests answers to one important question: to what extent does Malay custom (adat) which is seen by many Malays as based on the religion of Islam, but which also has strong pre-Islamic currents, ${ }^{1}$ influence the structure of the applied Family law? This social transformation is the basis for the proposal of an alternative framework that is based on religion and appropriately named as 'qur'annic governance'. The second part is an exploration of the role of

* Zaleha Kamaruddin is Professor at the Kulliyah of Law at the International Islamic University Malaysia (IIUM). 
the individual as khalïfah ([God's] vicegerent) and the duty of man as head of the family. The discussion is based on governance at the individual level and its relation with the family, community, and State level. The third part highlights the extent of state intervention in family matters in the context of marriage. Some relevant principles of Islamic jurisprudence are briefly addressed to justify the discretionary power of the state (in the name of 'good governance') to intervene for the purpose of preserving the family institution.

\section{Current Challenges to the Family}

'Good governance' is a necessary requirement for the family institution which is a very important component for the growth and continuity of human civilisation. In the Malaysian context, informal governance is made through the primary social unit of Malay-Muslim society, that is, of the family. Prior to the country's independence from Britain in 1957, this was often the extended family rather than the nuclear family as found in the West. Malay-Muslim society is 'unusual' in that there is almost a complete lack of a formal structure binding the Malays together. The only substantial social organisation is that of the village (kampong), often made up of closely related individuals on an extended family basis. The manifested interaction is that of small close-knit communities in which organisation, administration and other social and cultural activities are regulated on a communal basis.

To the Malay-Muslim community, the family is a basic component of a looselystructured kinship system. A complex series of linkages based on blood, marriage, and other putative relationships brings together a number of individuals into a common universe of kinship containing various categories and groups of kinsmen. Malay kinship is governed by two sets of adat (custom): Adat Temenggung ${ }^{2}$ and Adat Perpatih. ${ }^{3}$ Both represent Malay conceptions of law, and the legitimacy of these traditions can be said to derive from moral principles as well as from custom and long usage. ${ }^{4}$

The tradition of the Temenggung has been described as more autocratic and less democratic because it places power and authority solely in the hands of the ruler. The latter tradition centres on the principle of collective responsibility; the ruler is sovereign but the authority and power of the ruler is within the limits that have been laid down in its code. Family structure under the Adat Perpatih is explained in the following sayings:

The world has its kings, the luak (civet) has its chief;

the tribe has its headman,

the family has its elders. 
The matrilineal system is composed of traditionally corporate groups of increasing inclusiveness viewed from the smallest unit, the family. A group of families interlinked by descent from a common ancestor constitute the group, called perut. A group of perut, affiliated to each other by actual or putative descent, constitutes a suku (clan). District and state traditional political and administrative organisation was based on this larger kinship structure.

These factors, therefore, have varying normative and moral influences on the behaviour and organisation of a family group, being a small unit within a whole corporate system, without, however, impinging on the basic autonomy of the family. More often than not, the extended family type exerts greater influence on the running of its component family units, thus affecting the internal process of decision-making. It is, therefore, useful to be aware of the larger frame of kinship structure in any evaluation of a family system to understand fully some of the background factors affecting its organisation and function.

The Malay family has a reciprocal kinship or moral obligation with other groups of kinsmen. This network affects the family in varying degrees depending very much on various factors of closeness or remoteness, in terms of descent, residence and generation status. The closer the link, the greater the degree of influence.

In the context of the marriage system under the Adat Perpatih, it is a system of exogamy within their tribes. This means that the preference is for a person to marry outside the clan but within the tribes. It is also 'matrilocal', that is, it is compulsory for a husband to live in the wife's place, if not with the wife's family. ${ }^{5}$ The Perpatih tradition has made marriage an institution through which the whole host of relations and tribal organisations are bound into a cohesive whole. An example of family governance is the following:

Warder of the wife is the husband,

Warder of the husband, his wife's family. ${ }^{6}$

In both Malay societies that practise Adat Perpatih and Adat Temenggung, the position of primary authority in a family falls on the man. The father is head of the household, but the woman may manage the actual running of the household. The Malays' image of their society is such that the husband is regarded as the primary authority.

The traditional Malay family conformed more to the norm of an extended family whereby two or more family units, together with other kin members, lived together as a domestic or household unit. However, internal developments within the family, economic ability, conflict of interests and optimum residential capacity have split the family and thus a new domestic, autonomous and independent family unit has developed. After independence, urbanisation, industrialisation and educational developments have pushed and attracted younger families into urban areas. 
These factors have exposed young men and women to wider sections of the population as a 'field of choice'. According to traditional norms of close agricultural societies, spouse selection was more or less set within the general organisation of the family, kinship or community at large. Marriage was regulated by religious teachings. While this remains true now, the field of choice depends on individual contacts and preference.

At the present time, marriage is increasingly based on romantic love and customs are not fully adhered to in every case. The traditional function of marriage brokers in the arrangement of marriages has almost died out. While no general data are available on the current general pattern of spouse selection, the present situation has affected the mean age at first marriage for women, which has risen from 17 to 23 years. The delay in marriage is closely related to the current family structure. High mobility and higher cost of maintenance have encouraged the formation of nuclear families, living away from parents and free from kinship constraints. This will eventually force households to be founded more on conjugal relations through law than on kinship linkages, especially when the married partners are strangers to each other prior to marriage.

The urban setting greatly stresses the need for greater social mobility, higher attainment and comfortable living. The strong family constraint which was once highly regarded does not operate anymore. As a response to the general pattern of development, the erosion of traditional values and the radical changes occurring in the family, a kind of socio-cultural reaction has emerged. Materialistic affluence has led to the breakdown of a more familiar pattern of social relations, aspirations, and beliefs.

Specifically, the emergence of the industrial era, the assertions of individualism, the passion for freedom and liberty, the change in the cultural and social climate, and the women's liberation movement, have all contributed in moulding the attitudes of the Malay-Muslim society towards marriage. These changes in Malaysian Muslim family life over the past 53 years after independence are profound and dramatic. For example, after the Second World War, the states of Kelantan and Terengganu recorded some of the highest rates of divorce in the world (seven out of ten marriages ended in divorce). ${ }^{7}$ However, this has declined over the last two decades to only $10-16$ per cent. Researchers have shown that divorce amongst Malays is culturally rather than religiously determined. ${ }^{8}$

The age of Muslim couples at their first marriage has increased from 17 to 25 for men and 15 to 23 for women. Due to social changes, more women are petitioning for divorce compared to men. Changes in the values and perceptions of the spouses in relation to the family institution are based on varieties of social, cultural, political and economic factors. 
The increasing enthusiasm for higher education (professional education) and the employment of women played a vital role in influencing the values of men and women thus changing their attitude towards marriage and divorce. ${ }^{9}$

These changes have not only contributed considerably to the breaking of traditional structure of Malaysian marriages but also to the increase in the rate of divorce in Malaysian society. The development of urban living has led to uprooting and greater social isolation. Marriage has changed from being institutional to companionate. Freeman describes this as "two individuals rather than two lineages, on the child-centred household, on the quasi emancipation of women, and on the structural isolation of the nuclear family from the kinship system and the community". ${ }^{10}$

The revolution that has taken place in the recent past in relation to the family which is considered at one time a holy matrimony from the sharī $a h$ point of view and this branch of the law is a striking example of how the law is keeping pace with the needs and aspirations of modern society. These factors justify the alternative method, i.e. using the legal mechanism - Islamic Family Law - to govern Malay-Muslim society. Reasons for doing so are as follows: first, as many scholars have argued, families are not really private or autonomous institutions. Families exercise authority over an important set of functions with relatively minor supervision from the state, but the boundaries of family membership and the boundaries of family jurisdiction are defined by Islamic law. This was true even before the introduction of the Islamic Family Law Act in 1984. Second, times have changed. The traditional conception no longer corresponds with contemporary views of the family as a social institution with a particular structure and function. The tradition that families should be autonomous, self-governing, and independent still has emotional force, but it is based on an increasingly outdated and inaccurate depiction of family life.

\section{Qur'ānic Governance}

How do we develop a model of good family governance appropriate for contemporary families? There are a range of approaches but a reliance on qur'ānic based theories holds a number of advantages. One of the reasons for that is, practically, it will be more acceptable by the States in determining family governance. Another basis would be that the distribution of power and resources within the family will shape those of the larger community. The family serves as one of society's primary sources of moral education. It is in the family that we first encounter issues involving power and justice. Because of the primacy of family life as the determinant of social structure, individual values are crucial to the formulation of family governance.

As pointed out above, in both Malay societies through the practice of Adat Perpatih and Adat Temenggung, the position of primary authority in a family is 
put on the man as head of the household. The Malays' image of their society is such that the husband is regarded as the primary authority. This concept is actually based on the Qur'ān where Allāh has created man as His representative (vicegerent; khaliffah). He has endowed man with reason, physical and intellectual capabilities and knowledge. These potentials are given to man as a trust (amānah).

Ibrahim Zein has rightly pointed out that as khalifah, they are supposed to have acquired better judgment and self control to understand Divine guidance. He highlights the concept of trust (amānah) which determines the individual's relationship with the family, society, state, and government and the humanity at large. Man is said to be attached to these institutions both materially and spiritually. He further elaborates that amānah establishes man's responsibility toward his kin, other human beings and socio-political institutions. This concept resolves the issues pertaining to the rights and responsibilities of individuals in every facet of his life. He summed it up as "someone's right is someone's responsibility". ${ }^{11}$

Applying the same concept of amānah as stated by the Qur'ān as the cornerstone to the establishment of institutions to govern society, the family as the smallest unit of society would be the first institution to practise it. This idea is founded on the fact that the fourth chapter of the Qur'ān (known as al-Nisā', 'The Women'), which deals with 'good governance', describes the idea of absolute human equality in the context of the family. In the family, legally married man and wife are entrusted with the amānah of raising their children by providing maintenance, care, and education. The Qur'ān reminds mankind that when amānah are fulfilled, it would bring good to himself.

The concept of khalifah which is governance at the individual level encompasses the concept of amānah (trust), and 'adālah (justice) as the essence of qur'ānic guidance on 'good governance'. The Qur'ān revealed that amānah must be fulfilled with 'adālah (justice). ${ }^{12}$ Another important component for good family governance is shüra - consultation among family members. The Qur'ān emphasises this in various issues of governance. ${ }^{13}$ The concept of shürā underlines the participation of all members of the family.

Extending these explanations in the context of the family, the man as head of the household has a 'contract' with his family through the trust given to him by his family members to fulfil that trust. This responsibility is heavy and would necessitate cooperation from his family members through shūrā. The community as a whole also becomes responsible for the accomplishment of the trust. However, no meaningful, extensive and long lasting cooperation is possible without effective governance. Extension of this would be another alternative mechanism for effective governance, i.e. through law. Figure 1 shows this relationship and its connectivity to qur'ānic guidance. 


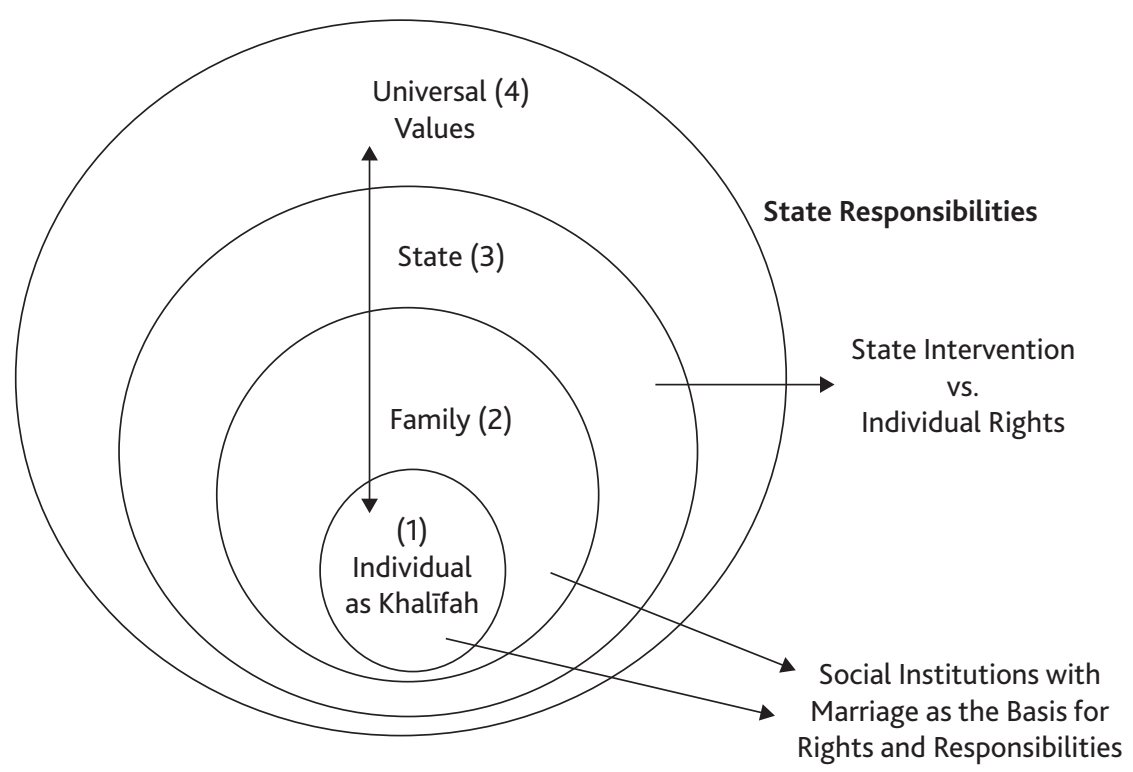

Figure 1 'Qur'ānic governance' on the family

\section{Islamic Family Law}

The $\operatorname{shari~}^{-}$ah has instituted a just, sound and sublime rule for the regulation and functioning of the family. The most important principle underlying any legislation for the family should consist in consolidating the bonds of marriage and kinship. It has been one of the most important objectives of the shari' $a h$ to give special attention to marriage, because it constitutes the basic principle of the family. ${ }^{14}$

In Malaysia, a significant shift in legal authority over family life has ushered in the transformation of Islamic family law. Family law is the province of state governance, and the states are evidently sovereign in this area. The federal government played a major role over the past three decades in transforming and codifying the sharī'ah in relation to Islamic family law. The Technical Committee in Civil and Sharì ah Laws under the Department of Islamic Development, Prime Minister's Department has drafted extensive legislative family laws since the 1980s. These laws which are based on the shari 'ah are readily adopted by the states as model laws.

A focus on family governance will enable us to highlight the relations between certain areas of the family law. All these areas derive their sources from the Qur'ān. However, as part of a larger set of changes in family law, an emphasis on individuals as khaliffahs as pointed out earlier is significant as it highlights the concept of responsibility. All these reforms have been characterised as 'proto-responsibility', 
because responsibilities and rights coexist with one another. The law based on the shari ${ }^{\prime} a h$ is that the husband as the ruler of the household has the right to be obeyed by his wife and children. The obligation of his wife and children were contingent on the proper exercise of his authority.

For a successful implementation of family governance, having adequate laws relating to marriage is pertinent. In the next section, the legal provisions relating to marriage under the present Islamic Family Law are outlined before commentaries are made. From a liberal approach, there is a movement to introduce stricter laws which have affected marriage patterns in Malaysia. Below are regulations relating to marriage.

\section{Marriage}

(a) Void marriages:

Section 11 of the Act provides that a marriage shall be void unless all the conditions necessary according to a ruling of the shari $\bar{\imath}^{-} a h$ ( $h u k m$ shar $\stackrel{\imath}{\imath}$ ) for the validity thereof are satisfied. The Federal Territories Act does not detail the conditions for a valid marriage. These are however given in the Kelantan Islamic Family Law Enactment of 1983. The details of these various conditions are also set out in the Schedule to the Enactment.

Hukm shar ' $\bar{l}$ is defined in the Federal Territories Act as the laws of Islam in the Shāfi 'ì, Hanbalī, Hanafī and Mālikī 'schools' of Islamic jurisprudence, but this definition is not included in the Kelantan Enactment, which seems to follow more closely the laws of the Shāfi ìs.

(b) Marriage in contravention of the Act:

Initially, Section 12 of the Act provides that a marriage in contravention shall not be registered under the Act, but later amended it to provide that a marriage which has been solemnised contrary to any provision of Part II of the Act, but is otherwise valid according to a hukm shar ' $\bar{l}$, may be registered under the Act with an order from the court and payment of the penalty provided by the Act.

Section 40(2) of the Act provides that any person who marries or purports to marry or goes through a form of marriage with, any person contrary to any of the provisions of Part 11 of the Act (dealing with marriage) commits an offence and shall be punishable with a fine not exceeding RM 1,000 or with imprisonment not exceeding six months or with both such fine and imprisonment.

(c) Consent:

Section 13 of the Act provides that a marriage shall not be recognised and shall not be registered under the Act unless both parties to the marriage have consented thereto and either: 
(i) The $w \bar{a} l \bar{\imath}$ or legal guardian of the woman has consented thereto in accordance with the hukm shar ' $\bar{l}$, or

(ii) The sharī'ah judge having jurisdiction in the place where the woman resides or any person generally or specially authorised in that behalf by the $\operatorname{shar}^{-}$' $a h$ judge has after due inquiry in the presence of all parties concerned, granted his consent thereto as wali raja in accordance with the hukm shar ' $\bar{l}$. Such consent may be given wherever there is no wāli by nasab (blood relationship) in accordance with the hukm shar ' $\bar{l}$ available to act or if the wāli cannot be found or the $w \bar{a} l \bar{l}$ refuses his consent without sufficient reason.

(d) Persons ascribing to religions other than Islam:

Section 10 of the Act provides that no Muslim man shall marry a non-Muslim except from what is referred to as kitābiyyah (in usual parlance a Christian or Jew), while no Muslim woman shall marry a non-Muslim. Strangely, the Shāfi 'ī 'school' of law has adopted a rather restrictive and narrow definition of kitäbiyyah (and which is not shared by the followers of the Hanafī 'school', numerically the strongest 'school' among the Sunnites):

(i) a woman whose ancestors were from Bani Ya 'qub (that is, a Jewess);

(ii) a Christian woman whose ancestors were Christians before the "call to prophethood' of Muhammad (one remembers, an event that is believed to have taken place in the 7 th century CE, i.e. about 1,400 years ago!); or

(iii) a Jew whose ancestors were Jews before the prophethood of Jesus Christ.

(e) Persons by whom marriages may be solemnised:

Section 7 of the Act provides that a marriage in the Federal Territories shall be in accordance with the Act and shall be solemnised in accordance with Hukum Syara' by:

(i) the $w \bar{a} l \bar{l}$ in the presence of the Registrar of Muslim Marriages;

(ii) the representative of the $w \bar{a} l \bar{l}$ in the presence of and with the permission of the Registrar; or

(iii) the Registrar as the representative of the $w \bar{a} l \bar{l}$. Where a marriage involves a woman who has no wālì (guardian) in accordance with the hukm shar $\bar{l}$, the marriage shall be solemnised only with the wali raja, i.e. guardian delegated by the Sultan.

(f) Minimum age of marriage:

The current provision, i.e. Section 8 , discourages marriage between parties where either one or both are below the age of 18, except where the shari 'ah judge has granted his permission in writing in special circumstances. In the Federal Territories, it is provided that a marriage in contravention of the Section, if nevertheless valid 
under Muslim law, can be registered with the permission of the court, subject to the imposition of the penalty provided by the Act. The policy of the law in discouraging teenage marriages will in effect reduce the number of divorces which are brought by young people who do not understand the heavy commitments a marriage entails.

(g) Permissions to marry:

Section 27 of the Act provides that the Registrar, on being satisfied of the truth of the matters in the application for permission to marry and where the man is already married that the permission of the shari 'ah judge required by Section 23 has been granted shall at any time after the application issue to the applicants his permission to marry in the prescribed form.

(i) Polygamous marriage:

Islamic law allows a restricted form of polygamy. In Malaysia, polygamy is controlled through Family Legislations in the States. No man who has already married may marry again, except with the prior permission of the $\operatorname{sharī}^{-} a h$ judge. The court may only grant permission if satisfied that:

a. the proposed marriage is just and necessary, having regard to such circumstances, as among others, the following, that is to say, sterility, physical infirmity, physical unfitness for conjugal relations, wilful avoidance of an order for the restitution of conjugal rights or insanity on the part of the existing wife or wives;

b. the applicant has such means as to enable him to support as required by the Muslim law all his wives and dependants, including persons who would be his dependants as a result of the proposed marriage;

c. the applicant would be able to accord equal treatment to all his wives as required by the Muslim law;

d. the proposed marriage would not cause harm affecting the existing wife or wives in respect of religion, life, body, mind or property.

In all these interventions, often the legislation seeks to codify the law, but for its interpretation, the shari 'ah court will refer to the sources of Islamic law, including the Qur'ān, the Sunnah and the views of the jurists. For example, Section 11 of the Islamic Family Law (Federal Territories) Act provides that a marriage shall be void unless all the conditions necessary, according to the stipulations of the $\operatorname{sharl}^{-} a h$, for the validity thereof are satisfied. This provision shows the necessity to refer to the sources of Islamic law to ascertain the conditions necessary for the validity of marriage.

The provisions outlined above show the extent of intervention by the State on family matters relating to marriage. However, this intervention is considered valid 
as its authority is authorised by the sharī'ah. The principles of siyāsah shar 'iyyah, mașlahah and sadd al-dhara $\bar{l}$ are used interchangeably to denote discretionary power of the state. The balance of interests in family matters and the spirit of the shari $\bar{i}^{\prime} a h$ must be maintained, and for this reason the role and intervention of the state becomes more important.

\section{Concluding Remarks and Recommendations}

This article is an exploration on the concept of 'qur'ānic governance' on the family institution. It is not a conclusive document, because

- understanding the role of the shari ${ }^{-} a h$, its unique approach, and the ways in which statements of the shari 'ah are codified into contemporary law, and how best courts interpret the law, pose important questions requiring careful articulation.

This is especially true in cases where justifying the autonomy of the family, we could no longer rely on the tradition of the past where it is said that the Muslim government had a very limited function. Reason for this is simply because the Muslims were spread out over such a wide territory that the State then could not reach them. Others also opined that Islamic government is a very limited one. First, not every aspect of Islam is entrusted to the government to enforce. It is assumed that it is the nature of a unitarian religious order of society that the individual should enjoy a wide degree of autonomy. Moreover, not everything is practically capable of enforcement through government law. ${ }^{15}$

The present Malaysian Islamic Family Law Act of 1984 - a federal law for the Federal Territories - is a codified law containing provisions which are sharī'ahcompliant in the sense that their sources are derived from the Qur'ān and the Sunnah. Because of this, the shari ' $a h$ attaches great importance to fulfilment of Muslims' obligation towards their legal government. There is a hadīth, related by Nāfi', according to which 'Abd-Allāh b. 'Umar has heard from the Prophet:

He who withdraws his hand from obedience [to the amir; i.e. the ruler] will have nothing in his favour when he meets Allāh on the Day of Resurrection.

The sharī 'ah attaches great importance to fulfilment of the Muslims' obligation towards their legal government and considers it as a religious obligation. However, 'Abd al-Raḥmān Tāj has rightly pointed out that no policy can be called siyāsah shar 'iyyah unless it observes the limits of moderation, which errs neither toward severity nor to laxity, for both will lead to injustice and the loss of rights. ${ }^{16}$ 
- The state, therefore, must be extra careful in its intervention because it has to ensure equilibrium of reasonable balance between the autonomy of the family and the state and also to understand the extent of the role that religion plays in public life.

\section{Notes}

1. Adat Bersendi Huku, Hukum Bersendi Kitabullah; see Mohamed Abdul Rahman, Dasar-Dasar Adat Pepatih (Kuala Lumpur: Pustaka Antara, 1964), 39.

2. Adat or custom is an indispensable institution in Malay sociological analysis. It represents the formal and conscious beliefs of the Malays which often predate their conversion to Islam and from which one could trace cultural and social production of ideas and relations in the wider society.

3. The matriarchal Adat Perpatih in its traditional statement which is known as perbilangan or customary saying. It has been handed down from generation to generation and governs land tenure, lineage and the election of various traditional chiefs. As far as rules relating to marriage are concerned, this community follows Islamic law.

4. Richard James Wilkinson, "Law: Introductory Sketch and the Ninety-Nine Laws of Perak", in: Richard James Wilkinson et al. (eds), Papers on Malay Subjects (Kuala Lumpur: Federated Malay States Government Press, 1908), 2.

5. Mohamed Abdul Rahman, Dasar-Dasar Adat Pepatih, 39.

6. "Kunci bini laki; Kunci Semenda tempat semenda"; the translation quoted is that of A. Caldecott, "Jelebu Customary Songs and Sayings", Journal of the Malayan Branch of the Royal Asiatic Society 78 (1918), 3-41.

7. Yoshihiro Tsubouchi, "Islam and Divorce Among Malay Peasants", in: Shinichi Ichimura (ed.), Southeast Asia in Nature, Society and Development (Honolulu HI: University of Press of Hawaii, 1977), 28.

8. Zaleha Kamaruddin, "Divorce Laws in Malaysia (Civil and Shari'ah)", Malayan Law Journal (2005), 21-2.

9. Ibid.

10. M.D.A. Freeman, "Legal Responses to Marriage Breakdown”, Current Legal Problems 31 (1978), 121.

11. Ibrahim M. Zein et al., "Qur'anic Guidance on Good Governance”, in: Abdullah al Ahsan and Stephen B. Young (eds), Guidance for Good Governance: Explorations in Qur'anic, Scientific and Cross-Cultural Approaches [jointly published in 2008 by the International Islamic University (IIUM) Malaysia and the Caux Round Table], available online at http://csis.org/event/quranicguidance-good-governance (accessed on 7 July 2010), 9-37.

12. Qur'ān 4:58.

13. Qur'ān 3:159; 42:38.

14. For a detailed discussion, see Ibn 'Ashūr, Maqāṣid al-sharī'ah al-islāmiyyah (Amman: Dār al-Nufays, 1999), 189-95.

15. Hasan Turabi, "Principles of Governance, Freedom, and Responsibilities in Islam", The American Journal of Islamic Social Sciences 4, no. 1 (1987), 6.

16. Mohammad Yusuf Abdul Kadir, "State Intervention in Marriage: Does It Infringe Human Rights", in: Zaleha Kamaruddin (ed.), Islamic Family Law: New Challenges in the 21st Century (Kuala Lumpur: International Islamic University (IIUM) Malaysia, 2004), quoting 'Abd al-Rahmmān Tāj, Al-Siyāsah al-shar 'îyyah wa-'l-fiqh al-islāmī (Cairo: Mațba ah Dār al-Ta'līf, 1953), 34. 